\title{
Correction to: Functional outcomes in Hirschsprung disease patients after transabdominal Soave and Duhamel procedures
}

\author{
Amira Widyasari, Winona Alda Pavitasari, Andi Dwihantoro and Gunadi ${ }^{*}$ (D)
}

\section{Correction to: BMC Gastroenterology (2018) 18:56} https://doi.org/10.1186/s12876-018-0783-1

Following publication of the original article [1], the authors reported an error in the name of the second author; this should read Pavitasari.

The original article [1] has been corrected. procedures. BMC Gastroenterol. 2018;18:56. https://doi.org/10.1186/ s12876-018-0783-1.

\section{Publisher's Note}

Springer Nature remains neutral with regard to jurisdictional claims in published maps and institutional affiliations.

Published online: 30 September 2021

\footnotetext{
Reference

1. Widyasari A, Pavitasari WA, Dwihantoro A, et al. Functional outcomes in

Hirschsprung disease patients after transabdominal Soave and Duhamel
} 